\title{
Leadership Role for Food and Beverage SME in Banjar City West Java
}

\author{
Witjaksono', Andri Irawan ${ }^{2}$, Lukman Munawar Fauzi ${ }^{3}$, Arlan Sidha ${ }^{4}$ \\ \{witjaksono83@gmail.com ${ }^{1}$, andri.irawan@lecture.unjani.ac.id ${ }^{2}$, lukmanulhakim.unjani@gmail.com ${ }^{3}$, \\ siddha_arlan@yahoo.com ${ }^{4}$ \} \\ 1,2,3,4 International Relation Department, Faculty of Social and Political Science, Jenderal Achmad \\ Yani University, Terusan Jenderal Sudirman Street, Cimahi, Jawa Barat Indonesia
}

\begin{abstract}
Leadership is an important aspect that must be well managed by the company in carrying out its business activities. The development of small business in Banjar City are rapidly developed these day. Type of this research conducted by using qualitative research. The population in this research are all the merchant of food and beverage SME in Banjar City. Sampling is done by using sampling assessment. The number of samples set in this study is 50 respondents of food and beverage SME merchant in Banjar city. Based on the results and discussion that has been done by researchers can be concluded that the merchant of food and beverage SME in its business activities should pay attention to the aspects of the leadership in conducting their business in addition to meet the completeness of their SMR business lisence and legality.
\end{abstract}

Keywords: leadership, Food and beverage SME

\section{Introduction}

Banjar City is a land area of about $131.97 \mathrm{~km} 2$ and is at an altitude of between 20 and 500 meters above sea level (MDPL) with tropical climates. Most of the area of Banjar city located at an altitude of less than 100 MASL which reaches $87.10 \%$ and the remaining $12.90 \%$ located at the altitude of 100-500 MASL. Banjar Region that formerly known as Administrative city under Ciamis Regency, was formed into a new autonomy in 2003. Currently Banjar city have 16 villages, 9 urban village, 103 sub village, 297 hamlet and 1,146 neighborhood divided into 4 sub-districts of Purwaharja sub-district in the north, Banjar Subdistrict in the west, Pataruman subdistrict in the south and Langensari Sub-district to the east.[1]

The development of small businesses in Banjar city is developing rapidly with the number of about $46.67 \%$ with $20.31 \%$ of employment. The majority of small businesses in Banjar City are snacks businesses that utilize agricultural products such as bananas, soybeans, etc. This development caused by the successness of all the merchant in regulating the ways and which the business is. Based on the data, it can be concluded that the aspect of leadership is one of the elements that impacts the successness of the management of food and beverage SME positively.

According to The EFQM (The European Foundation of Quality Management), one of its fundamental aspects is the successness of an organization based on the ability to manage people who have talent and aptitude. The aspect of leadership is also indispensable to support SME hit in managing its business activities. [2] stated that leadership demands in SME should be able to lead with vision, inspiration and integrity. So it can be concluded that the success of 
SME should be supported by the right leadership. It is also followed by [3] stated that leadership success in every situation and time with different objects requires a high level of flexibility. Based on that aspect of leadership becomes an important thing to be aware of in managing an organization

Based on this central issue of the research is the leadership role for food and beverage SME in Banjar City West Java.

\section{Literature Review}

Leadership is an important aspect that must be well managed by the company in carrying out its business activities. The company in its efforts to create excellence operational requires other elements such as leadership and business environment. Leadership has a direct impact on the employee capability excellence development, increased morale and job assistance, also encourages creativity and effective working relationships in maintaining stability [4]

Leaders should be able to develop the vision, support the strategies and plans, provide motivation and give managers the opportunity through their authority to encourage employees to work well [5]. [6] In his research concluded that there is an empirical positive relationship between transformational leadership, leadership service and leadership participation on effective and efficient leadership. [6] In his research that has been done at Netherlands by using 199 companies as a respondents concluded that there is a positive relationship between transformational leadership and leadership participation with effective and efficient leadership while service leadership demonstrates a negative relationship on effective and efficient leadership value.

[3] stated that the age-development perspective is a useful alternative for generation representation, as it captures more of the age-related dynamics of relevant leadership, followers and leadership development. In the end, his research served as an foundation of basic moratorium to be placed on the application of generational ideas and generational differences to leadership, research, and practice theories. [7] In his research in schools in Sarawak, he described it as one of the attempts to take the first step towards integrating leadership competencies with abilities that could lead to leadership effectiveness.

[8] concluded in his research that a game-based learning approach is an effective approach to the development of leadership skills and key skills developed are: motivation, facilitation, coaching, change Mindset, and communication. A significant originality of the study was the process of analogy between the game situation and the organization life that resulted in the creation of a typological leadership.

[9] In his research in Netherlands that concluded environmental leaders were influenced not only by changes in the broader political and social environment, but also by increasing awareness of the differences between external and internal factors Country. In newer cases the leadership focus shifts from substantive ambitions on to governance. Although records of the fading implementation in the Netherlands still show the form of entrepreneurship and, in particular, cognitive leadership.

\section{Research Methodology}

The type of research done by using descriptive research with a qualitative approach. [10] stated that descriptive research provides important information about "what" and provides the opportunity to understand and critique in a practice on an education system while [11] stating that qualitative research is a means to explore and understand the meaning of individuals or 
groups consider social or human problems. The research process involves emerging questions and procedures; Collecting data in participant settings; Analyzing inductive data, buildings from specific to general themes; and make interpretations of data meanings. Recent written reports have a flexible writing structure.

The population in this research is the all the of food and beverage SME merchant in Banjar City. The method of sampling collected systematically that known as a non probability sampling, and afterwards all the sample be selected to meet the criteria of the researcher (purposive sampling). Purposive sampling is part of a sampling assessment which for the sampling is based on subjective considerations based on some criteria set by researchers based on their knowledge and experience. The number of samples set in this study is 50 respondents of food and beverage SME merchant in Banjar city. Validity test in qualitative research according to [12] is one that has the standard of reliability, acquisition, dependence and certainty by using the product moment and Cronbach's alpha correlation analysis. Data collection techniques are conducted by observations, interviews and polls. Qualitative analysis techniques using three phases namely data reduction phase, data display phase and conclusion drawing/verification phase. [13]

\section{Results and Study}

Respondents in this research are all the food and beverage SME merchant in Banjar City West Java. The respondents profile can be seen in table 1 below:

Table 1. Respondents Characteristics

\begin{tabular}{|c|c|c|c|}
\hline Category & Alternative Answer & Frequency & Percentage (\%) \\
\hline \multirow[t]{5}{*}{ Education Level } & Elementary school & 6 & 12 \\
\hline & Junior high school & 11 & 22 \\
\hline & High school & 26 & 52 \\
\hline & Diploma & 2 & 4 \\
\hline & Bachelors & 5 & 10 \\
\hline Profession & Entrepreneur & 50 & 100 \\
\hline \multirow[t]{4}{*}{ Age } & $<20$ year & 4 & 8 \\
\hline & $20-30$ year & 21 & 42 \\
\hline & $31-40$ year & 14 & 28 \\
\hline & $>40$ year & 11 & 22 \\
\hline \multirow[t]{3}{*}{ Type of product } & Food & 36 & 72 \\
\hline & Beverage & 6 & 12 \\
\hline & Food and Beverage & 8 & 16 \\
\hline \multirow[t]{2}{*}{ Gender } & Male & 23 & 46 \\
\hline & Female & 27 & 54 \\
\hline \multirow[t]{3}{*}{ Ownership Status } & Owners and managers & 27 & 54 \\
\hline & Manager/Employee & 18 & 36 \\
\hline & Owner & 5 & 10 \\
\hline \multirow[t]{2}{*}{ Business license } & Owned & 23 & 46 \\
\hline & Nought & 27 & 54 \\
\hline \multirow[t]{3}{*}{ Legality } & $\begin{array}{l}\text { MUI (Indonesian Ulema } \\
\text { Council) }\end{array}$ & 1 & 2 \\
\hline & $\begin{array}{l}\text { Depkes (Indonesian } \\
\text { Departement of health) }\end{array}$ & 6 & 12 \\
\hline & $\begin{array}{l}\text { PIRT (Indonesian Home } \\
\text { industry product lisence) }\end{array}$ & 1 & 2 \\
\hline
\end{tabular}




\begin{tabular}{|l|l|c|c|}
\hline & Nought & 42 & 84 \\
\hline Business Experience & $\leq 1$ year & 8 & 16 \\
\cline { 2 - 4 } & $2-5$ year & 20 & 40 \\
\cline { 2 - 4 } & $6-10$ year & 8 & 16 \\
\cline { 2 - 4 } & $>10$ year & 14 & 28 \\
\hline
\end{tabular}

Source : Data Processed on 2019

Based on the table above the respondents research education level of food and beverage SME merchant in Banjar city are mostly 52\% SLTA. Food and beverage SME merchant is 100\% entrepreneur. Food products are the most sold by the food and beverage SME merchant of about $72 \%$. For gender, female gender are dominating for $54 \%$. The ownership status is $54 \%$ owner and manager. For the food and beverage SME merchant have a business permit of about $46 \%$ and $84 \%$ do not have legality. Business experience of food and beverage SME merchant amounted of about $40 \%$ at levels 2-5 years experience. The validity test conducted by the researchers using the analysis of correlation product moment that show as the following results

Table 2. Validity Test

\begin{tabular}{|c|l|c|c|}
\hline No & \multicolumn{1}{|c|}{ Statement } & Result & Conclusion \\
\hline 1 & $\begin{array}{l}\text { Good business vision in business activities development } \\
\text { and implementation }\end{array}$ & 0,884 & Valid \\
\hline 2 & $\begin{array}{l}\text { Good strategy and business plan in business activities } \\
\text { Implementation }\end{array}$ & 0,892 & Valid \\
\hline 3 & $\begin{array}{l}\text { Motivate employees to be better consistently } \\
\text { Authorize and give confidence to employees in the } \\
\text { business activities undertaken consistently }\end{array}$ & 0,734 & Valid \\
\hline
\end{tabular}

Source : Data Processed on 2019

While the reliability test that has been done by researchers using cronbach's alpha test resulted in a value of about 0.804 so that it can be inferred the existing data has a very high degree of reliability. Subsequent researchers conducted a perception analysis of respondents about leadership variables using distribution analysis frequency to determine the category of each question item. The results of the analysis of perception of respondents on the leadership variables are as follows:

Table 3. Respondents ' Response to "Development and Implementation of Good Business Vision in Business Activities) Statement

\begin{tabular}{|c|l|c|c|c|}
\hline STATEMENT & \multicolumn{1}{|c|}{ DESCRIPTION } & FREQUENCY & PERCENTAGE & AVERAGE \\
\hline $\begin{array}{c}\text { Good business } \\
\text { vision in } \\
\text { business } \\
\text { activities } \\
\text { development and } \\
\text { implementation }\end{array}$ & Highly agree & 40 & 80 & \multirow{2}{*}{4,8} \\
\cline { 2 - 5 } & Agree & 10 & 0 & \\
\cline { 2 - 5 } & Hesitant & 0 & 0 & \\
\cline { 2 - 5 } & Highly Disagree & 0 & 100 & \\
\cline { 2 - 5 } & TOTAL & 50 & & \\
\end{tabular}

Source : Data Processed on 2019 
According to the table above, the majority of respondents answered highly agree of about $80 \%$ while the remaining answered is $20 \%$ agreed. The respondents response results are very important $(4,8)$ because the obtaining value are between 4,21-5,00 which means the good business vision in business activities development and implementation in food and beverage SME become a very important role.

Subsequent, respondents responses to the statement regarding the implementation of a good business plan strategy in business activities can be described in the following table 3:

Table 4. Respondents ' Response to the „Strategy and Good Business Plan in Business Activities Implementation" Statement

\begin{tabular}{|c|c|c|c|c|}
\hline STATEMENT & DESCRIPTION & FREQUENCY & PERCENTAGE & AVERAGE \\
\hline \multirow{6}{*}{$\begin{array}{l}\text { Good strategy and } \\
\text { business plan in } \\
\text { business activities } \\
\text { implementation }\end{array}$} & Highly agree & 41 & 82 & \multirow{6}{*}{4,82} \\
\hline & Agree & 9 & 18 & \\
\hline & Hesitant & 0 & 0 & \\
\hline & Disagree & 0 & 0 & \\
\hline & Highly Disagree & 0 & 0 & \\
\hline & TOTAL & 50 & 100 & \\
\hline
\end{tabular}

Source : Data Processed on 2019

According to the table above, the majority of respondents answered $82 \%$ highly agree while the remaining $18 \%$ answered agree. The respondents response results are very important (4.82) because its obtaining a value between 4.21-5.00 which means implementing a good business plan strategy in business activities in food and beverage SME become a very important role

Subsequent respondents ' responses related to the statement "motivating employees to be better consistently" statement can be explained in the table below:

Table 5. Respondents Response to the "Motivating Employees to Become Better Again Consistently"

\begin{tabular}{|l|l|c|c|c|}
\hline \multicolumn{1}{|c|}{ STATEMENT } & \multicolumn{1}{|c|}{ DESCRIPTION } & FREQUENCY & PERCENTAGE & AVERAGE \\
\hline \multirow{2}{*}{$\begin{array}{l}\text { Motivate employees } \\
\text { to be better } \\
\text { consistently }\end{array}$} & Highly agree & 48 & 96 & \\
\cline { 2 - 4 } & Agree & 2 & 4 & \multirow{2}{*}{4,96} \\
\cline { 2 - 5 } & Hesitant & 0 & 0 & \\
\cline { 2 - 5 } & Disagree & 0 & 0 & \\
\cline { 2 - 5 } & Highly Disagree & 0 & 100 & \\
\cline { 2 - 5 } & TOTAL & 50 & & \\
\end{tabular}

Source : Data Processed on 2019

According to the table above, the majority respondent are $96 \%$ highly agree, while the remaining $4 \%$ answered agreed. Response results of the respondent is very important category (4.96) because obtaining a value between 4.21-5.00 means always motivate the employees to be better at food and beverage SME have a very important role. 
Furthermore the respondent response regarding to the "Giving authority and giving confidence to the employees in the business activities consistently" performed can be explained in the following table:

Table 6. Respondents Response to the "Authorizes and Gives Employees Confidence in the Business Activities Undertaken Consistently" Statement.

\begin{tabular}{|c|c|c|c|c|}
\hline STATEMENT & DESCRIPTION & FREQUENCY & PERCENTAGE & AVERAGE \\
\hline \multirow{6}{*}{$\begin{array}{l}\text { Authorize and give } \\
\text { confidence to } \\
\text { employees in the } \\
\text { business activities } \\
\text { undertaken } \\
\text { consistently }\end{array}$} & Highly agree & 48 & 96 & \multirow{6}{*}{4,96} \\
\hline & Agree & 2 & 4 & \\
\hline & Hesitant & 0 & 0 & \\
\hline & Disagree & 0 & 0 & \\
\hline & Highly Disagree & 0 & 0 & \\
\hline & TOTAL & 50 & 100 & \\
\hline
\end{tabular}

Source : Data Processedon 2019

According to the table above, the majority respondent answered the importance of the statement is $96 \%$ highly agree while the remaining $4 \%$ just agree to the statement. The respondents response results are very important category based on (4.96) because it's obtaining a value between 4.21-5.00 which means give authority and give confidence to employees consistently in on food and beverages SME business activities have a very important role.

Subsequent respondents responses to the statements regarding variables can be described as following table:

Table 7. Average of Each Item Statement on the Respondent's Response to Leadership in Food and Beverage SME in Banjar City West Java

\begin{tabular}{|l|c|c|}
\hline \multicolumn{1}{|c|}{ Statements } & Average & Category \\
\hline Good business vision in business activities development and implementation & 4,80 & \\
\hline Good strategy and business plan in business activities Implementation & 4,82 & \multirow{2}{*}{ Very Important } \\
\hline Motivate employees to be better consistently & 4,96 & \\
\cline { 1 - 2 } $\begin{array}{l}\text { Authorize and give confidence to employees in the business activities undertaken } \\
\text { consistently }\end{array}$ & 4,96 & \\
\hline Total & 4,89 & \\
\hline
\end{tabular}

Source : Data Processed on 2019

Based on the table above, it can be concluded that aspects of leadership including in the category are very important for all the food and beverages SME merchant in Banjar City West Java.

\section{Conclusion}

Based on the results and study that has been done by researchers, can be concluded that the merchant of food and beverage SME in its business activities should pay attention to the leadership aspects in conducting their business in addition to meet the completeness of their SMR business lisence and legality. 


\section{References}

[1] Badan Pusat Statistik Kota Banjar, "Statistik Daerah Kota Banjar 2018," 2018.

[2] R. M. Shehadeh, M. Maqableh, M. O. Al-zoubi, A. O. Akhorshaideh, and M. K. Alshami, "Review the Operational Excellence Factors of Service Firms: A Literature Review," Eur. J. Bus. Manag., vol. 8, no. 3, pp. 1-11, 2016.

[3] C. W. Rudolph, R. S. Rauvola, and H. Zacher, "Leadership and generations at work: A critical review," Leadersh. Q., vol. 29, no. 1, pp. 44-57, 2018.

[4] P. McAdam, R. Keogh,W. El Tigani, a. and Gardiner, "An exploratory study of business excellence implementation in the United Arab Emirates (UAE) public sector: Management and employee perceptions," Int. J. Qual. Reliab. Manag., vol. 30(4), pp. 426-445, 2013.

[5] H. Masa'deh, R., Maqableh, M., \& Karajeh, "A Theoretical Perspective on the Relationship between Leadership Development, Knowledge Management Capability, and Firm Performance.," Asian Soc. Sci., vol. 10(6), pp. 128-137, 2014.

[6] M. F. Van Assen, "Total Quality Management \& Business Excellence Exploring the impact of higher management' s leadership styles on Lean management," Total Qual. Manag., vol. 0, no. 0, pp. 1-30, 2016.

[7] M. Jayan, K. W. Bing, and K. Musa, "Investigating the Relationship of Adaptive Leadership and Leadership Capabilities on Leadership Effectiveness in Sarawak Schools," Procedia - Soc. Behav. Sci., vol. 224, no. August 2015, pp. 540-545, 2016.

[8] M. J. Sousa and Á. Rocha, "Skills for disruptive digital business," J. Bus. Res., vol. 94, no. August 2017, pp. 257-263, 2019.

[9] M. Wiering, D. Liefferink, and B. Beijen, "The internal and external face of Dutch environmental policy: A case of fading environmental leadership?," Environ. Sci. Policy, vol. 81, no. December 2017, pp. 18-25, 2018.

[10] C. R. dan J. N. L. Lochmiller, An Introduction To Education Research. Connecting Methods To Practice. Unitade States of America: SAGE Publication, Inc, 2016.

[11] J. W. Cresswell, Research Design: Qualitative, Quantitative and Mixed Methods Approaches, vol. 91. London, 2014.

[12] Satori, Djam'an dan Komariah, Aan, Metode Penelitian. Bandung: Alfabeta, 2017.

[13] Sugiyono, Metode Penelitian Bisnis (Pendekatan Kuantitatif, Kualitatif dan $R$ n D). Bandung: Alfabeta, 2015. 